\title{
Emergency management of bleeding esophageal varices: Drugs, bands or sleep?
}

\author{
Brian M Yan MD FRCPC, Samuel S Lee MD FRCPC
}

BM Yan, SS Lee. Emergency management of bleeding esophageal varices: Drugs, bands or sleep? Can J Gastroenterol 2006;20(3):165-170.

Variceal bleeding is a severe complication of cirrhosis leading to significant morbidity and mortality. Treatment of acute variceal bleeding has improved dramatically since the era of the mechanical balloon tamponade. These advances include endoscopic band ligation or sclerotherapy, and vasoactive pharmacological options such as somatostatin, octreotide, vasopressin and terlipressin. Evidence from a multitude of clinical trials and meta-analyses comparing endoscopic and pharmacological treatments suggests near equivalence in efficacy for initial hemostasis, mortality and rate of rebleeding. This raises the question of whether on-call gastroenterologists should be performing emergency endoscopic treatment in the middle of the night or start pharmacological treatment and delay endoscopy until optimal patient and working conditions the next morning. The present review analyzes the available comparative data between endoscopic and pharmacological treatment options. Although the literature cannot yet definitively answer the question posed, the authors suggest that delaying endoscopic treatment until the next morning may be the most reasonable practical approach.

Key Words: Acute variceal bleeding; Band ligation; Octreotide; Sclerotherapy; Somatostatin; Terlipressin; Vasopressin

\section{Le traitement d'urgence des hémorragies oesophagiennes variqueuses : les médicaments, la ligature élastique ou le sommeil?}

Les hémorragies variqueuses sont une complication grave de la cirrhose, associées à une morbidité et à une mortalité importantes. Le traitement des hémorragies variqueuses aiguës s'est considérablement amélioré depuis l'arrivée de la tamponnade mécanique par ballonnet. Les progrès réalisés dans le domaine comprennent la ligature élastique endoscopique et la sclérothérapie ainsi que les médicaments à action vasomotrice comme la somatostatine, l'octréotide, la vasopressine et la terlipressine. Des données provenant de plusieurs essais cliniques et de méta-analyses et comparant les interventions endoscopiques au traitement médicamenteux semblent indiquer que les deux approches donnent des résultats quasi équivalents en ce qui concerne l'efficacité de l'hémostase initiale, la mortalité et le taux de récidive hémorragique. L'observation soulève toute la question du traitement, notamment de la conduite à tenir par les gastroentérologues de garde : vaut-il mieux pratiquer une intervention endoscopique d'urgence au beau milieu de la nuit ou prescrire un traitement médicamenteux et reporter l'endoscopie au lendemain matin lorsque le patient est en meilleur état et les conditions de travail, plus appropriées ? Le présent article passe en revue les données disponibles comparant les interventions endoscopiques au traitement médicamenteux. Même si la documentation ne fournit pas de réponse définitive à la question, les auteurs croient que le report de l'endoscopie au lendemain matin serait peut-être la meilleure conduite à tenir.

Many strides in therapy have been made in recent years resulting in improved mortality after variceal bleeding (3). In-hospital mortality from acute variceal bleeding has significantly improved from over $40 \%$ in 1980 to $14 \%$ in 2000 . This is due to a combination of decreased rebleeding and bacterial infection rates. On multivariate analysis, endoscopic and antibiotic treatments were independent predictors of survival. Endoscopic therapy has gained widespread application from $6 \%$ in 1980 to $90 \%$ in 2000 , of which $81 \%$ of procedures were performed in the first $24 \mathrm{~h} \mathrm{(3).}$

Recent guidelines (4-8) have been endorsed by the American College of Gastroenterology, which include both endoscopic and pharmacological treatments. Endoscopic treatment, mainly variceal band ligation or sclerotherapy, has proved to be effective in controlling acute variceal bleeding. A recent survey of American College of Gastroenterology members showed that $40.8 \%$ of members used band ligation, $36.3 \%$ rhythm of portal pressure $(1,2)$.

Division of Gastroenterology, University of Calgary, Calgary, Alberta

Correspondence: Dr SS Lee, Health Sciences Centre, 3330 Hospital Drive Northwest, Calgary, Alberta T2N 4N1. Telephone 403-220-8457, fax 403-270-0995, e-mail samlee@ucalgary.ca

Received for publication August 16, 2005. Accepted August 18, 2005 
TABLE 1

Endoscopic treatment options

\begin{tabular}{|c|c|c|}
\hline & Band ligation & Sclerotherapy \\
\hline \multicolumn{3}{|l|}{ Efficacy, \% } \\
\hline Initial hemostasis & 80 to $100^{*}$ & 76 to 92 \\
\hline Rebleeding & 6 to $30^{\dagger}$ & 16 to 53 \\
\hline Mortality & 19 at 30 days $^{\ddagger}$ & 35 at 30 days \\
\hline Contraindications & $\begin{array}{l}\text { Heavily scarred mucosa } \\
\text { from previous } \\
\text { treatments }\end{array}$ & $\begin{array}{l}\text { Previous deep ulcerations } \\
\text { from sclerotherapy }\end{array}$ \\
\hline \multicolumn{3}{|l|}{ Complications } \\
\hline \multirow[t]{10}{*}{ Total } & $5 \%$ & $29 \%$ \\
\hline & Esophageal ulcer & Aspiration \\
\hline & Bacterial peritonitis & Empyema \\
\hline & & ARDS \\
\hline & & Esophageal ulcer \\
\hline & & Esophageal stricture \\
\hline & & Perforation \\
\hline & & Peritonitis \\
\hline & & Mediastinitis \\
\hline & & Sepsis \\
\hline \multirow[t]{2}{*}{$\operatorname{Cost}^{\S}$} & $\begin{array}{l}\text { Cook (USA) multiband } \\
\text { six shooter: } \$ 200\end{array}$ & $\begin{array}{l}\text { Tetradecyl } 2 \mathrm{~mL} \text { vial } \\
(60 \mathrm{mg}): \$ 5\end{array}$ \\
\hline & & $\begin{array}{l}\text { Marcon-Haber varices } \\
\text { injector: } \$ 95\end{array}$ \\
\hline \multirow[t]{2}{*}{ Comments } & Expertise required & Technically easy \\
\hline & Limited viewing field & Improved visualization \\
\hline
\end{tabular}

Data from references 16 and 17. *OR 1.14, 95\% Cl 0.44 to 2.90 (versus sclerotherapy); †OR $0.52,95 \% \mathrm{Cl} 0.37$ to 0.74 (versus sclerotherapy); ${ }^{\circ} \mathrm{OR} 0.67$, $95 \% \mathrm{Cl} 0.46$ to 0.98 (versus sclerotherapy): §Calgary Health Region costs in Canadian dollars. ARDS Acute respiratory distress syndrome

used sclerotherapy and $6.2 \%$ used both modalities emergently for variceal bleeding. Octreotide was used in only $52.6 \%$ of patients on index bleeding and vasopressin in 9.6\% (7).

Multiple pharmacological options are now available $(9,10)$. Recent studies have shown that it may be as effective as emergency endoscopic treatment and, therefore, may be appropriate as first-line treatment. It is unclear whether emergency endoscopic treatment is more effective than initial pharmacological treatment with delayed endoscopic therapy. The present review summarizes the available evidence for the initial treatment of acute variceal bleeding.

\section{ENDOSCOPIC TREATMENT OPTIONS}

\section{Sclerotherapy versus band ligation}

Endoscopic sclerotherapy (ESL) was the first available endoscopic therapy for bleeding varices (Table 1). It involves the injection of a sclerosant agent (100\% ethanol, ethanolamine, polidocanol or sodium tetradecyl sulfate) into or adjacent to a varix with the goal of obliteration through irritation and thrombosis. Previous studies (11) have shown its efficacy in controlling variceal hemorrhage, reducing rebleeding and need for blood transfusions, and possibly reducing mortality. The complications related to ESL are significant, including large, deep esophageal ulcerations, strictures, mediastinitis, pleural effusions, sepsis and death.

Endoscopic variceal band ligation (EBL) is an attractive firstline therapy because of its improved efficacy and complication profile compared with ESL. Several randomized controlled trials have compared EBL with ESL in acute variceal bleeding. Gimson et al (12) reported the safety and effectiveness of EBL. In that study, 103 patients were randomly assigned to band ligation or sclerotherapy, of whom $39 \%$ and $47 \%$, respectively, had active bleeding at index endoscopy. Both methods were equally effective in controlling initial hemorrhage (91\% versus $92 \%)$. Rebleeding was significantly less in the EBL group, but other outcomes and complication rates were similar. Sarin et al (13) randomly assigned 95 patients to EBL or ESL and showed $86 \%$ versus $80 \%$ (not significant) efficacy, respectively, in initial hemostasis. The EBL group had significantly less rebleeding, development of portal hypertensive gastropathy and variceal recurrence. Lo et al (14) showed superiority of EBL versus ESL for initial control (97\% versus 76\%), one-month treatment failure ( $8 \%$ versus $30 \%)$, blood transfusions and complication rates ( $5 \%$ versus $29 \%$ ). There was a trend toward a one-month mortality benefit $(19 \%$ versus $35 \%, \mathrm{P}=0.19)$. Laine et al (15) showed improved rebleeding rates (26\% versus $44 \%$ ) and decreased complications ( $0 \%$ versus $33 \%$ ) in favour of EBL over ESL.

Two meta-analyses of EBL and ESL have been completed. Gross et al (16) showed no significant difference between EBL and ESL for initial hemostasis (91\% versus 81\%, respectively). Laine and Cook (17) showed a significant benefit of EBL over ESL for reduction in rebleeding rate (OR $0.52,95 \%$ CI 0.37 to 0.74 , number needed to treat $=4$ ), overall mortality rate (OR $0.67,95 \%$ CI 0.46 to 0.98 , number needed to treat $=10$ ) and mortality due to bleeding (OR $0.49,95 \%$ CI 0.24 to 0.996). Esophageal strictures were less frequent in EBL (OR 0.1, 95\% CI 0.03 to 0.29), but no other differences in complications were found.

On the basis of equal or superior efficacy in initial hemostasis, improved rebleeding rate, decreased complication rates and possible mortality benefit, EBL should replace ESL as first-line endoscopic treatment.

\section{Other techniques}

Other viable techniques for hemostatic control include endoscopic clip or loop placement. Small, randomized trials $(18,19)$ suggest promise with these options. These therapies may be possible first-line options if larger, randomized trials confirm their efficacy and safety. Cyanoacrylate glue injection is generally reserved for gastric variceal treatment. Previous small studies (20) have shown its effectiveness in esophageal varices; however, serious complications including distal embolization causing stroke, pulmonary embolus and mesenteric thrombosis have limited its use.

\section{PHARMACOLOGICAL TREATMENT OPTIONS}

\section{Somatostatin and analogues}

Somatostatin and its longer-acting analogues (octreotide and vapreotide) decrease portal pressure by reducing portal flow secondary to splanchnic vasoconstriction (Table 2). Results from randomized controlled trials $(21,22)$ conflict about the efficacy of somatostatin versus placebo. A meta-analysis by Gotzsche et al (23) showed no significant benefit over placebo for hemostasis or 30-day mortality.

Octreotide has been studied extensively but no true placebocontrolled trial has been published, because all trials included adjunctive endoscopic therapy. A meta-analysis by Corley et al (24) showed improved hemorrhage control compared with 
TABLE 2

Somatostatin and analogues

\begin{tabular}{|c|c|c|c|}
\hline & Somatostatin* & Octreotide $^{\dagger}$ & Vapreotide $^{\ddagger}$ \\
\hline Dose and duration & $\begin{array}{l}250 \mu \mathrm{g} \text { IV bolus then } 250 \mu \mathrm{g} / \mathrm{h} \\
\text { infusion } \times 24 \mathrm{~h} \text { to } 168 \mathrm{~h}\end{array}$ & $\begin{array}{l}50 \mu \mathrm{g} \text { to } 100 \mu \mathrm{g} \text { IV bolus then } 25 \mu \mathrm{g} / \mathrm{h} \text { to } \\
50 \mu \mathrm{g} / \mathrm{h} \text { infusion } \times 24 \mathrm{~h} \text { to } 120 \mathrm{~h}\end{array}$ & $50 \mu \mathrm{g} \mathrm{IV} \mathrm{bolus} \mathrm{then} 50 \mu \mathrm{g} / \mathrm{h} \times 120 \mathrm{~h}$ \\
\hline Initial hemostasis & 60 to 92 & 84 to 95 & 69 \\
\hline Rebleeding & 15 & $19(0.46,0.32 \text { to } 0.67)^{\S}$ & 16 at 42 days \\
\hline Mortality & $\begin{array}{l}9 \text { to } 38 \text { at } 42 \text { days } \\
\quad(1.16,0.67 \text { to } 2.01)^{\S}\end{array}$ & 31 at 60 days $(0.81,0.48 \text { to } 1.35)^{\S}$ & 14 at 42 days \\
\hline \multicolumn{4}{|l|}{ Complications } \\
\hline Total, \% & 6.5 & 26 & 6 \\
\hline Severe & $\begin{array}{l}\text { Virtually none compared } \\
\text { with placebo }\end{array}$ & $\begin{array}{l}\text { Pneumonia } \\
\text { Cardiac arrythmia } \\
\text { Paralytic ileus } \\
\text { Pulmonary edema }\end{array}$ & $\begin{array}{l}\text { No difference in major adverse events } \\
\text { compared with placebo }\end{array}$ \\
\hline & & Nausea & \\
\hline & & Encephalopathy & \\
\hline & & Headache & \\
\hline & & Infection & \\
\hline $\operatorname{Cost}^{\pi}$ & $\begin{array}{r}3 \text { mg vial: } \$ 220.50 \\
\text { (wholesale cost) }\end{array}$ & $\begin{array}{l}50 \mu \mathrm{g} \text { ampule: } \$ 4.99 \\
100 \mu \mathrm{g} \text { ampule: } \$ 9.42 \\
500 \mu \mathrm{g} \text { ampule: } \$ 44.27\end{array}$ & Not available \\
\hline Comments & $\begin{array}{l}\text { Conflicting RCTs } \\
\text { No significant difference compared } \\
\text { with placebo on meta-analysis }\end{array}$ & $\begin{array}{l}\text { All trials included endoscopic } \\
\text { treatment initially or after } 48 \mathrm{~h}\end{array}$ & $\begin{array}{l}\text { All patients received endoscopic } \\
\text { treatment in } 12 \mathrm{~h}\end{array}$ \\
\hline
\end{tabular}

Data from references ${ }^{2} 21-23,33$; ${ }^{3} 33,34,37$; and $\$ 25$. $\$ R R$ versus placebo, $95 \% \mathrm{Cl}$; ${ }^{\top}$ Calgary Health Region costs in Canadian dollars. IV Intravenous; $R C T$ Randomized controlled trial

alternative medical treatment, similar efficacy to immediate sclerotherapy and fewer major complications than with vasopressin/terlipressin. No mortality benefit was shown. Not included in the initial analysis was a large trial of octreotide versus placebo published only in abstract form. This did not show a benefit for octreotide alone but did improve the results of endoscopic therapy. Including the present study into a secondary analysis did not significantly change the conclusions.

Vapreotide, another somatostatin analogue, in combination with endoscopic therapy improved hemostasis and survival compared with endoscopic treatment alone in one study (25). This drug is not yet available in North America.

\section{Vasopressin and analogues}

Vasopressin and its analogues produce systemic and splanchnic vasoconstriction, thereby reducing portal hypertension (Table 3). A meta-analysis by D'Amico et al (26) showed a significant benefit for vasopressin compared with placebo for hemostasis (OR 0.22 , 95\% CI 0.12 to 0.43 ) but no mortality benefit. Because of significant side effects including myocardial infarction, mesenteric ischemia and death, vasopressin monotherapy is not recommended.

Terlipressin, a longer-acting vasopressin analogue, decreases portal and variceal pressure with fewer side effects than vasopressin. Ioannou et al (27) completed a systematic review of terlipressin, including 20 randomized trials with 1609 patients. Compared with placebo, terlipressin reduced mortality (RR 0.66, 95\% CI 0.49 to 0.88), improved hemostasis (RR 0.63, 95\% CI 0.45 to 0.89) and reduced emergency procedures or rebleeding. In addition to sclerotherapy, terlipressin improved hemostasis (RR 0.75, 95\% CI 0.58 to 0.96) and showed a trend toward mortality benefit (RR 0.74, $95 \%$ CI 0.53 to 1.04 ). No significant differences were found between terlipressin and balloon tamponade, sclerotherapy, somatostatin, octreotide or vasopressin for mortality, failure of hemostasis, rebleeding and procedures for uncontrolled bleeding. The one exception was the reduced failure of hemostasis favouring octreotide (OR 1.62, 95\% CI 1.05 to 2.50). However, this finding was based on three low-quality randomized controlled trials involving 203 patients. No difference was found in adverse events compared with any group.

\section{Activated recombinant factor VII}

Correction of coagulopathy may be beneficial in those who fail conventional therapy. In a small, open-label series of eight patients with refractory variceal bleeding, a single intravenous dose of recombinant activated factor VII achieved hemostasis in all cases (28). Larger, randomized trials are required before any conclusions can be drawn about the usefulness of this expensive drug. 
TABLE 3

Vasopressin and analogues

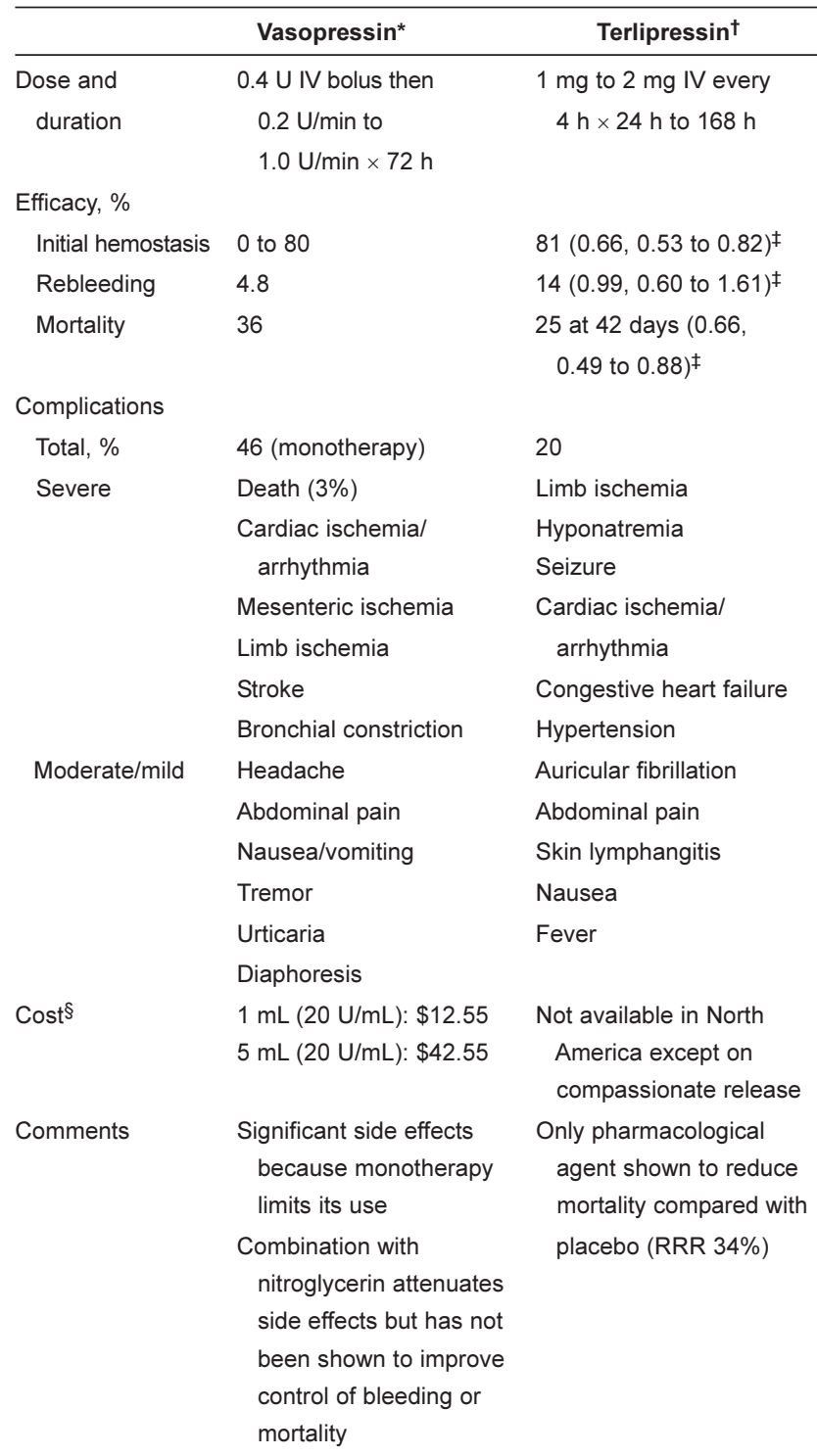

Data from references *26,38-40 and ${ }^{2} 27,31 ; \ddagger R R$ versus placebo, $95 \% \mathrm{Cl}$; $\S$ Calgary Health Region costs in Canadian dollars. IV Intravenous; RRR Relative risk reduction

\section{ENDOSCOPIC VERSUS PHARMACOLOGICAL TREATMENT}

Is endoscopic treatment superior to pharmacological treatment for acute variceal bleeding (Table 4)? All published studies have compared sclerotherapy with pharmacological therapy. No studies to date have directly compared emergency variceal band ligation with pharmacological therapy.

A Cochrane meta-analysis by D'Amico and colleagues (29) has addressed this issue. Fifteen studies were included: one compared sclerotherapy with vasopressin plus nitroglycerin, one with terlipressin, five with somatostatin and eight with octreotide. Sclerotherapy was not superior to terlipressin, somatostatin or octreotide for any outcome. Sclerotherapy was superior to vasopressin for control of bleeding and was associated with more adverse events than somatostatin. Combining all trials irrespective of control treatment did not result in any difference for failure of hemostasis, mortality or adverse events.
TABLE 4

Summary of endoscopic versus pharmacological treatment

\begin{tabular}{lcccccc}
\hline & EBL (\%) & ESL (\%) & SMS (\%) & OCT (\%) & VP (\%) & TLP (\%) \\
\hline Initial hemostasis & $80-100$ & $76-92$ & $60-92$ & $84-95$ & $60-80$ & 80 \\
Rebleeding & $6-30$ & $16-53$ & 15 & 19 & 4.8 & 14 \\
Mortality & 19 & 35 & $9-38$ & 31 & 36 & 25 \\
\hline
\end{tabular}

EBL Endoscopic band ligation; ESL Endoscopic sclerotherapy; OCT Octreotide; SMS Somatostatin; TLP Terlipressin; VP Vasopressin

The authors concluded that emergency sclerotherapy should not be first-line treatment for variceal bleeding and might be useful only in pharmacological failures.

Gross et al (16) concluded in a meta-analysis that band ligation appeared to be the most effective treatment and significantly more successful than pharmacological treatment for hemostasis (91\% versus $61 \%$ to $83 \%$ ). Banding was not statistically better than sclerotherapy. Sclerotherapy was not statistically better than pharmacological therapy.

Further studies of band ligation versus pharmacological treatment, both individually and in combination, need to be completed to definitively answer the question of optimal therapy.

\section{COMBINATION ENDOSCOPIC AND PHARMACOLOGICAL TREATMENT}

Banares et al (30) assessed the role of endoscopic plus pharmacological treatment versus endoscopic treatment alone for acute variceal bleeding. Eight studies with 939 patients were included in this meta-analysis. Sclerotherapy and band ligation were included with somatostatin, octreotide or vasopressin. Initial (RR 1.12, 95\% CI 1.02 to 1.23 ) and day 5 hemostasis (RR 1.28, 95\% CI 1.18 to 1.39 ) favoured combination therapy. Mortality was not significantly different (RR $0.73,95 \%$ CI 0.45 to 1.18 ).

The combination of terlipressin with sclerotherapy is also superior to sclerotherapy alone for initial hemostasis, number of emergency procedures required and rebleeding (27). There was a trend toward a mortality benefit for combination therapy (RR 0.74, 95\% CI 0.53 to 1.04). No trials have assessed combination endoscopic and pharmacological treatment versus pharmacological therapy alone.

\section{DELAYED ENDOSCOPIC THERAPY: CAN OR SHOULD WE WAIT?}

As asked in the introduction, should definitive endoscopic variceal eradication be done emergently, or delayed and completed electively? Targeted therapy is intuitively more effective if done with a clear, bloodless field of view in a hemodynamically stable patient. To date, however, the literature does not allow a definitive conclusion on this issue. In part, this is due to a heterogeneous definition of 'emergency' endoscopy. In the study by Lo et al (14), 42 of 71 patients had emergency endoscopy within $6 \mathrm{~h}$ of admission and all others within $12 \mathrm{~h}$. Emergency endoscopy by Laine et al (15), however, was within $24 \mathrm{~h}$ of admission (of note, with no vasoconstrictive medical treatment). Gimson et al and (12) and Sarin et al (13) did not specify their time to endoscopy. Mean time to endoscopic treatment has not been specified by any of these studies. In the terlipressin versus sclerotherapy study (31), time to random assignment and sclerotherapy was $6 \mathrm{~h}$. The meta-analysis by Gross et al (16) had times to endoscopy ranging from less than $3 \mathrm{~h}$ to less than $24 \mathrm{~h}$ after admission. In the European acute bleeding oesophageal 
variceal episodes study (32), sclerotherapy was performed within $8 \mathrm{~h}$ of presentation and was significantly easier to perform after somatostatin. Studies with octreotide by Hadengue (33) and Sung et al (34) delayed sclerotherapy for $48 \mathrm{~h}$ with no difference in control of bleeding or mortality. It is difficult, therefore, to define what entails 'emergency'. Endoscopy less than $6 \mathrm{~h}$ from admission may be an appropriate definition of 'emergency', less than $48 \mathrm{~h}$ as 'urgent' and more than $48 \mathrm{~h}$ as 'elective'.

The only study to directly address timing was by Shemesh et al (35), who analyzed whether emergency sclerotherapy was more effective than stabilization and elective sclerotherapy. Eightyfour patients with active variceal bleeding were randomly assigned to emergency sclerotherapy (within $6 \mathrm{~h}$ of presentation) or delayed ( $24 \mathrm{~h}$ to $48 \mathrm{~h}$ from presentation) depending on time of presentation. Those presenting from Sunday to Friday between 08:00 and 20:00 received emergency sclerotherapy. All others were delayed and received balloon tamponade and vasopressin, with sclerotherapy performed $24 \mathrm{~h}$ to $48 \mathrm{~h}$ after presentation. Emergency therapy stopped all acute bleeding and resulted in decreased rebleeding in hospital $(4.7 \%$ versus $17.1 \%, \mathrm{P}=0.027)$ and by one year $(7.0 \%$ versus $17.1 \%$, $\mathrm{P}=0.027)$. There was an insignificant trend showing improved mortality in hospital and at one, three and five years after follow-up in the emergency sclerotherapy group. Total mortality was 33\% in the emergency group and $44 \%$ in the delayed group ( $\mathrm{P}=$ not significant). The study would have been improved with a true randomized protocol rather than with a selection of a treatment group based on weekday and diurnal timing.

Given the similar efficacy for hemostatic control and mortality between pharmacological therapy and ESL, it seems reasonable to delay endoscopic treatment until optimal conditions or pharmacological failure occurs. Early endoscopic variceal banding may prove to be superior to pharmacological treatment, but direct comparison has not been evaluated.

\section{LIMITATIONS}

There are several limitations to the present review, because comparisons among studies are problematic. Differences in patient population (Child-Pugh class, etiology of cirrhosis, etc) may affect mortality data. Definitions for initial hemostasis range from $15 \mathrm{~min}$ to $72 \mathrm{~h}(16)$, which therefore affects definitions of rebleeding. Efficacy data for hemostasis must, therefore, be analyzed carefully and may not be directly comparable. Fortunately, more recent studies of variceal bleeding usually use consensus definitions of parameters such as hemostasis and rebleeding, thanks to the ongoing Baveno consensus conferences (36). Dose and duration of pharmacological agents vary among studies, which also may affect rebleeding rates, complication rates and mortality data. Excellent metaanalyses are available for octreotide, terlipressin and comparisons with sclerotherapy; however, pharmacological treatment and band ligation have not been directly compared. Therefore, while band ligation may appear to be superior to other methods of treatment, this conclusion is still premature. No studies to date have examined the cost-effectiveness of emergency endoscopic treatments.

\section{CONCLUSION}

If expertise is available, emergency band ligation is possibly the most effective first-line therapy for hemostatic control of acute variceal bleeding. Pharmacological therapy with terlipressin or octreotide should be initiated in all acute variceal bleeding and is appropriate first-line monotherapy in centres where band ligation is not available. Terlipressin is the only pharmacological agent shown to have mortality benefit, both alone and in combination with endoscopic treatment, but its availability in Canada is by compassionate-release protocol only. ESL is no better than pharmacological treatment and, given its potential complications, should not be used as firstline treatment. Combination endoscopic and pharmacological therapy improves initial hemostasis and early rebleeding rates but has not shown improved mortality compared with monotherapies.

Timing of definitive endoscopic treatment has not been clearly defined. Delaying endoscopic treatment may make it easier to perform in a clear, bloodless field, especially for band ligation. Current data suggest no difference in control of hemorrhage or mortality in the setting of pharmacological therapy if endoscopic treatment is delayed up to $48 \mathrm{~h}$. Therefore, to the probable delight of gastroenterologists on call, we recommend that emergency endoscopic treatment (less than $6 \mathrm{~h}$ from presentation) be reserved for continuing bleeding resistant to initial pharmacological treatment. Cost effectiveness analyses of emergency endoscopic treatment may allow more definitive practice recommendations.

ACKNOWLEDGEMENTS: Dr Samuel S Lee is supported by an Alberta Heritage Foundation for Medical Research Senior Scholarship award.

\section{REFERENCES}

1. Merican I, Sprengers D, McCormick PA, Minoli G, McIntyre N, Burroughs AK. Diurnal pattern of variceal bleeding in cirrhotic patients. J Hepatol 1993;19:15-22.

2. Garcia-Pagan JC, Feu F, Castells A, et al. Circadian variations of portal pressure and variceal hemorrhage in patients with cirrhosis. Hepatology 1994;19:595-601.

3. Carbonell N, Pauwels A, Serfaty L, Fourdan O, Levy VG, Poupon R. Improved survival after variceal bleeding in patients with cirrhosis over the past two decades. Hepatology 2004;40:652-9.

4. Hui AJ, Sung JJ. Endoscopic treatment of upper gastrointestinal bleeding. Curr Treat Options Gastroenterol 2005;8:153-62.

5. Harry R, Wendon J. Management of variceal bleeding. Curr Opin Crit Care 2002;8:164-70.

6. Ferguson JW, Tripathi D, Hayes PC. Review article:

The management of acute variceal bleeding. Aliment Pharmacol

Ther 2003;18:253-62.

7. Sorbi D, Gostout CJ, Peura D, et al. An assessment of the management of acute bleeding varices: A multicenter prospective member based study. Am J Gastroenterol 2003;98:2424-34.

8. Grace ND. Diagnosis and treatment of gastrointestinal bleeding secondary to portal hypertension. American College of Gastroenterology Practice Parameters Committee. Am J Gastroenterol 1997;92:1081-91.

9. D'Amico G. The role of vasoactive drugs in oesophageal varices. Expert Opin Pharmacother 2004;5:349-60.

10. Bosch J, Abraldes JG. Variceal bleeding: Pharmacological therapy. Dig Dis 2005;23:18-29.

11. Paquet KJ, Feussner H. Endoscopic sclerosis and esophageal balloon tamponade in acute hemorrhage from esophagogastric varices: A prospective controlled randomized trial. Hepatology 1985;5:580-3.

12. Gimson AE, Ramage JK, Panos MZ, et al. Randomised trial of variceal banding ligation versus injection sclerotherapy for bleeding oesophageal varices. Lancet 1993;342:391-4. 
13. Sarin SK, Govil A, Jain AK, et al. Prospective randomized trial of endoscopic sclerotherapy versus variceal band ligation for esophageal varices: Influence on gastropathy, gastric varices, and variceal recurrence. J Hepatol 1997;26:826-32.

14. Lo GH, Lai KH, Cheng JS, et al. Emergency banding ligation versus sclerotherapy for the control of active bleeding from esophageal varices. Hepatology 1997;25:1101-4.

15. Laine L, el-Newihi HM, Migikovsky B, Sloane R, Garcia F. Endoscopic ligation compared with sclerotherapy for the treatment of bleeding esophageal varices. Ann Intern Med 1993;119:1-7.

16. Gross M, Schiemann U, Mulhofer A, Zoller WG. Meta-analysis: Efficacy of therapeutic regimens in ongoing variceal bleeding. Endoscopy 2001;33:737-46.

17. Laine L, Cook D. Endoscopic ligation compared with sclerotherapy for treatment of esophageal variceal bleeding. A meta-analysis. Ann Intern Med 1995;123:280-7.

18. Yol S, Belviranli M, Toprak S, Kartal A. Endoscopic clipping versus band ligation in the management of bleeding esophageal varices. Surg Endosc 2003;17:38-42.

19. Naga MI, Okasha HH, Foda AR, et al. Detachable endoloop vs elastic band ligation for bleeding esophageal varices. Gastrointest Endosc 2004;59:804-9.

20. Feretis C. Tabakopoulos D, Benakis P, Xenofontos M, Golematis B. Endoscopic hemostasis of esophageal and gastric variceal bleeding with Histoacryl. Endoscopy 1990;22:282-4.

21. Valenzuela JE, Schubert T, Fogel RM, et al. A multicenter, randomized, double-blind trial of somatostatin in the management of acute esophageal varices. Hepatology 1989;10:958-61.

22. Burroughs AK, McCormick PA, Hughes MD, Sprengers D, D'Heygere F, McIntyre N. Randomized, double-blind, placebocontrolled trial of somatostatin for variceal bleeding. Gastroenterology 1990;99:1388-95.

23. Gotzsche PC, Gjorup I, Bonnen H, Brahe NE, Becker U, Burcharth F. Somatostatin $\mathrm{v}$ placebo in bleeding oesophageal varices: Randomised trial and meta-analysis. BMJ 1995;310:1495-8.

24. Corley DA, Cello JP, Adkisson W, Ko WF, Kerlikowske K. Octreotide for acute esophageal variceal bleeding: A meta-analysis. Gastroenterology 2001;120:946-54.

25. Cales P, Masliah C, Bernard B, et al. Early administration of vapreotide for variceal bleeding in patients with cirrhosis. $\mathrm{N}$ Engl J Med 2001;344:23-8

26. D'Amico G, Pagliaro L, Bosch J. The treatment of portal hypertension: A meta-analytic review. Hepatology 1995;22:332-54.

27. Ioannou GN, Doust J, Rockey DC. Systematic review: Terlipressin in acute oesophageal variceal haemorrhage. Aliment Pharmacol Ther 2003;17:53-64.
28. Romero-Castro R, Jimenez-Saenz M, Pellicer-Bautista F, et al Recombinant-activated factor VII as hemostatic therapy in eight cases of severe hemorrhage from esophageal varices. Clin Gastroenterol Hepatol 2004;2:78-84. (Erratum in 2004;2:352).

29. D’Amico G, Pietrosi G, Tarantino I, Pagliaro L. Emergency sclerotherapy versus vasoactive drugs for variceal bleeding in cirrhosis: A Cochrane meta-analysis. Gastroenterology 2003;124:1277-91.

30. Banares R, Albillos A, Rincon D, et al. Endoscopic treatment versus endoscopic plus pharmacologic treatment for acute variceal bleeding: A meta-analysis. Hepatology 2002;35:609-15.

31. Escorsell A, Ruiz del Arbol L, Planas R, et al. Multicenter randomized controlled trial of terlipressin versus sclerotherapy in the treatment of acute variceal bleeding: The TEST study. Hepatology 2000;32:471-6.

32. Averginos A, Nevens F, Raptis S, Fevery J. Early administration of somatostatin and efficacy of sclerotherapy in acute oesophageal variceal bleeds: The European acute bleeding oesophageal variceal episodes (ABOVE) randomised trial. Lancet 1997;350:1495-9.

33. Hadengue A. Somatostatin or octreotide in acute variceal bleeding. Digestion 1999;60:31-41.

34. Sung JJ, Chung SC, Lai CW, et al. Octreotide infusion or emergency sclerotherapy for variceal haemorrhage. Lancet 1993;342:637-41.

35. Shemesh E, Czerniak A, Klein E, Pines A, Bat L. A comparison between emergency and delayed endoscopic injection sclerotherapy of bleeding esophageal varices in nonalcoholic portal hypertension. J Clin Gastroenterol 1990;12:5-9.

36. de Franchis R. Evolving consensus in portal hypertension. Report of the Baveno IV consensus workshop on methodology of diagnosis and therapy in portal hypertension. J Hepatol 2005;43:167-76.

37. Jenkins SA, Shields R, Davies M, et al. A multicentre randomised trial comparing octreotide and injection sclerotherapy in the management and outcome of acute variceal haemorrhage. Gut 1997;41:526-33.

38. Saari A, Klvilaakso E, Inberg M, et al. Comparison of somatostatin and vasopressin in bleeding esophageal varices. Am J Gastroenterol 1990;85:804-7.

39. Tsai YT, Lay CS, Lai KH, et al. Controlled trial of vasopressin plus nitroglycerin vs. vasopressin alone in the treatment of bleeding esophageal varices. Hepatology 1986;6:406-9.

40. Gimson AE, Westaby D, Hegarty J, Watson A, Williams R. A randomized trial of vasopressin and vasopressin plus nitroglycerin in the control of acute variceal hemorrhage. Hepatology $1986 ; 6: 410-3$ 




The Scientific World Journal
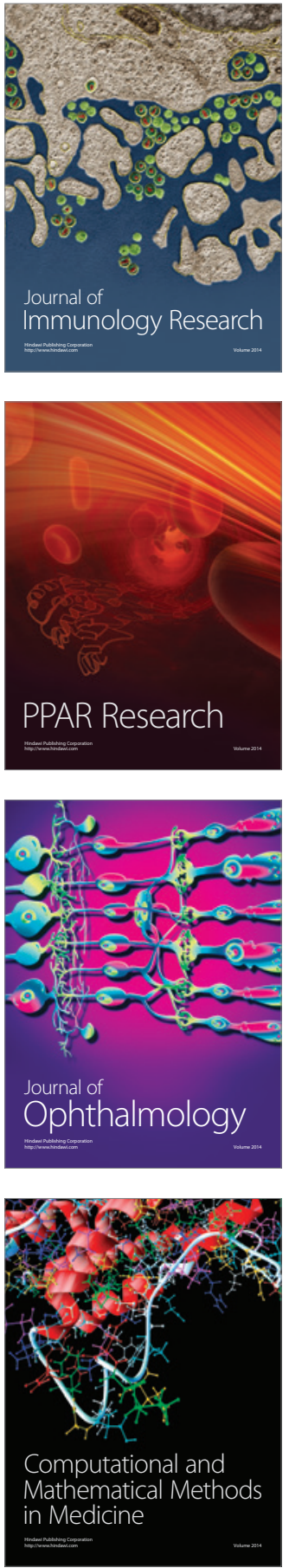

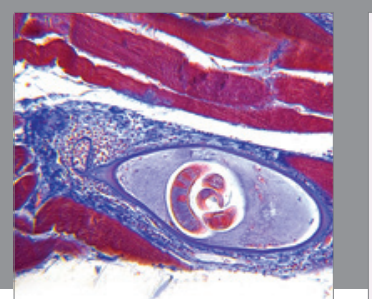

Gastroenterology Research and Practice

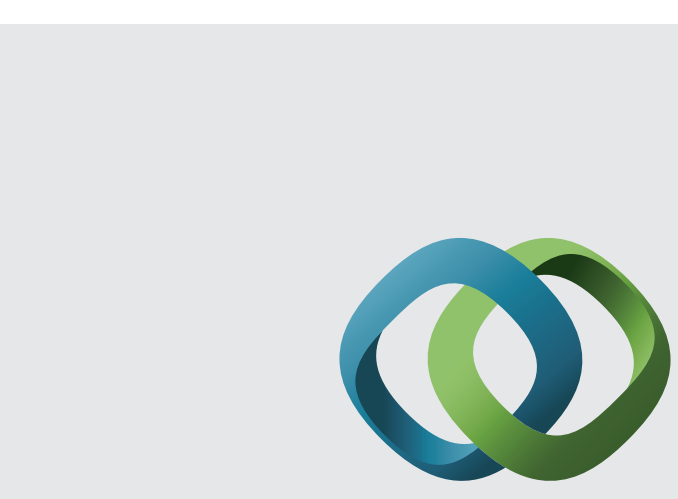

\section{Hindawi}

Submit your manuscripts at

http://www.hindawi.com
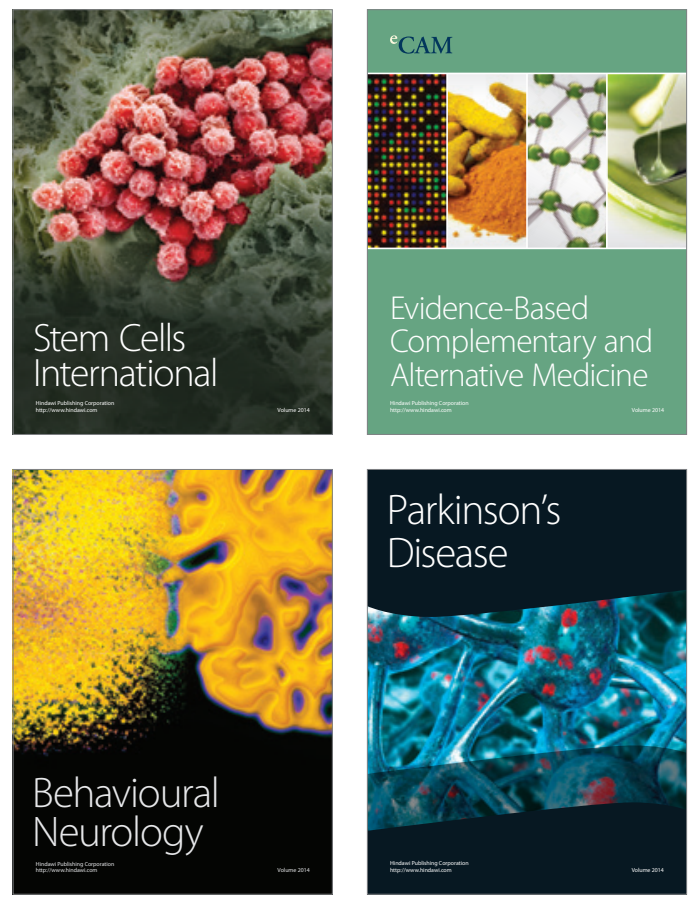
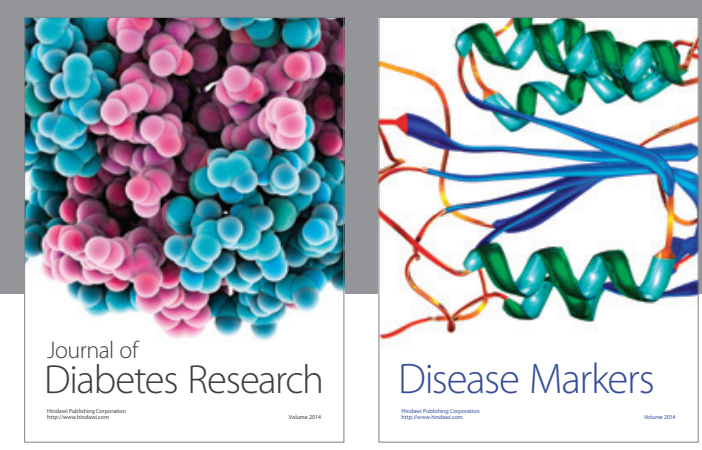

Disease Markers
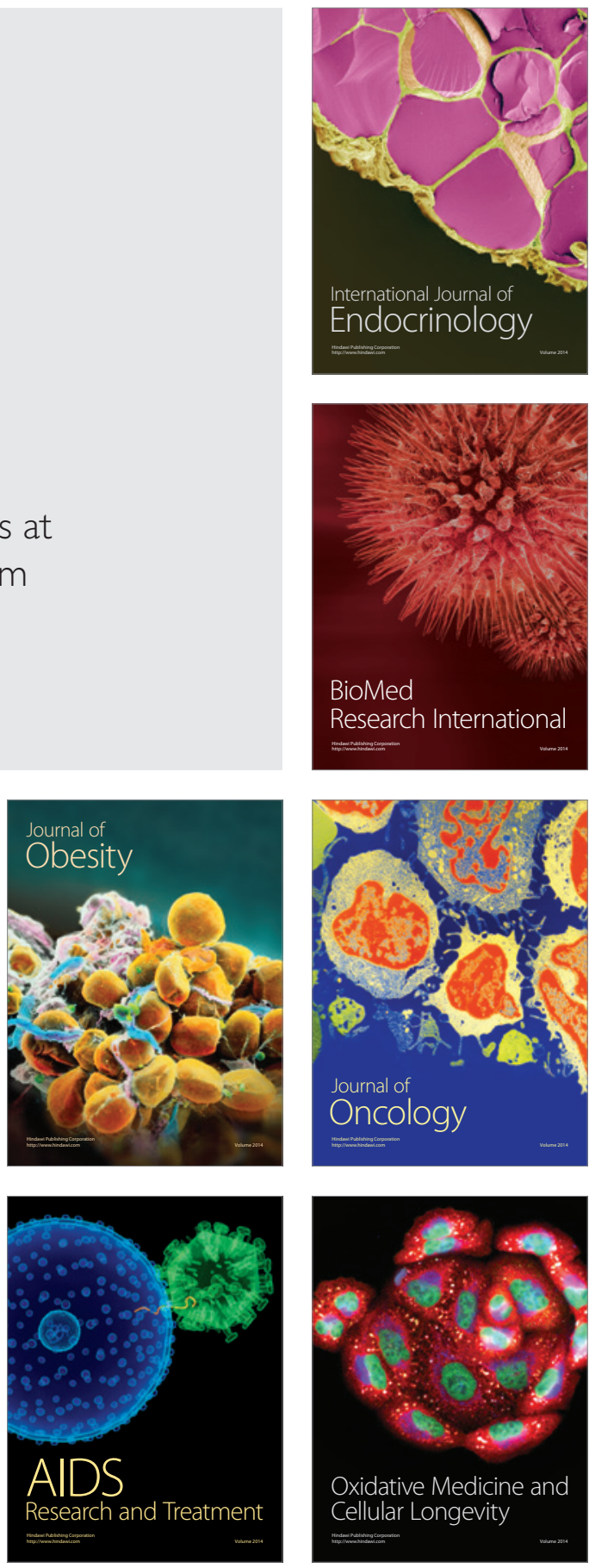